\title{
The effects of sedative agents used in intensive care unit on QT interval
}

\section{Yoğun bakım üinitesinde kullanılan sedatif ajanların QT intervaline etkisi}

\author{
Onur Avel ${ }^{1}$, Sinan Gürsoy², Kenan Kaygusuz², İclal Özdemir Kol${ }^{2}$, Cevdet Düğer ${ }^{3}$, Ahmet Cemil \\ İsbirr ${ }^{3}$, Mehmet Caner Mimaroğlu²
}

\author{
MD. Sivas Numune Hospital. Department of Anesthesiology, ${ }^{2}$ Professor, Cumhuriyet University School Of Medicine, Department of Anesthesiology, \\ ${ }^{3}$ Associated Professor, Cumhuriyet University School Of Medicine, Department of Anesthesiology \\ Corresponding author: Onur Avci, MD, Department of Anesthesiology, Sivas Numune Hospital, Sivas, Turkey \\ E-mail: dronuravci@gmail.com \\ Received/Accepted: November 25, 2016 / January 31, 2017
}

Conflict of interest: There is not a conflict of interest.

\section{SUMMARY}

Objective: The aim of this research is the effects of sedative drugs which are used on intensive care unit (ICU) patients on QT interval.

Method: 90 patients who were hospitalized at ICU due to respiratory insufficiency and connected to mechanic ventilator were included. After the respiratory and cardiac monitorizations were enabled on patient with respiratory insufficiency in ICU, 12 derivations ECG's were recorded, systolic blood pressure (SBP), diastolic blood pressure(DBP), mean arterial blood pressure(MABP), heart rate(HR) and peripheric oxygen saturation ( $\mathrm{SpO} 2)$ values were recorded simultaneously. These values were used as base. At 1st and 12th hours of sedation (midazolam, propofol or dexmedetomidin), 12 derivations ECG's were recorded and again, SBP, DBP, MBP, HR and SpO2 values were recorded. ECG's were recorded at the speed of $25 \mathrm{~mm} / \mathrm{s}$ and at the height of $1 \mathrm{mV}$. Among the derivations in ECG recordings, the longest QT interval was measured by 2 anesthesiologists who don't know the groups and by measuring the RR interval on the same derivation, $\mathrm{QTc}$ (corrected QT) interval was measured with Bazzet formula. (QTc $=\mathrm{QT}$ intervali / $\sqrt{ } \mathrm{RR}$ interval) .Measured QT and QTc values were recorded.

Results: When HR's at 12th hour were evaluated, HR at dexmedetomidin group was lower than both midazolam and propofol groups' HR and this was statistically significant $(p<0,05)$. When MABP's at 12 th hour were evaluated, MABP in propofol group was lower than dexmedetomidin group and this was statistically significant $(p<0,05)$. When $\operatorname{SpO} 2$ values at 12 th hour were evaluated, $\mathrm{SpO} 2$ values in midazolam group was significantly lower than the other 2 groups' $\mathrm{SpO} 2$ values. $(\mathrm{p}<0,05)$. For QT interval; dexmedetomidin prolonged the interval more than the other 2 agents both at $1 \mathrm{st}$ and 12th hours and this was statistically significant $(\mathrm{p}<0,05)$. There was statistically significant difference in QT intervals between propofol and midazolam groups at 12 th hours $(p<0,05)$. When QTc intervals were evaluated; only QTc values at 12th hour were different between different sedative agents and the QTc values in these groups belong to these different sedative agents were different each other and this was statistically different $(p<0,05)$. Dexmedetomidin prolonged QTc mostly however propofol shows favorable efficacy by shortening the QTc interval.

Conclusions: In our opinion, propofol is a good alternative sedative agent for dexmedetomidin and midazolam in patients with long QT interval because it shortens the QT interval however dexmedetomidin and midazolam can cause cardiac arrhythmia by prolonging QT interval. When making drug choice for sedation in ICU, patient's clinical situation, hemodynamic parameters and cardiac monitorization must be considered.

Keywords: Propofol, midazolam, dexmedetomidine, sedation, QT interval, . 


\section{ÖZET}

Amaç: Bu çalıșmanın amacı, yoğun bakım ünitelerinde (YBÜ) kullanılan sedatif ajanların QT intervali üzerine olan etkilerini araştırmaktır.

Yöntem: Calıșmaya solunum yetmezliği nedeniyle yoğun bakım ünitesine alınmıș, mekanik ventilatöre bağlı 90 hasta dahil edildi. Solunum yetmezliği nedeniyle yoğun bakım ünitesine alınan hastalar solunumsal ve kardiyak monitorizasyonları sağlandıktan sonra 12 derivasyon EKG'leri çekilerek, eşzamanlı olarak sistolik kan basıncı(SKB), diyastolik kan basıncı(DKB), ortalama kan basıncı(OKB), kalp atım hızı (KAH), ve periferik oksijen satürasyonu (SpO2) değerleri kaydedildi. Bu değerler baz olarak alındı. Hastalara sedasyon (midazolam, propofol veya deksmedetomidin) başlandiktan 1 ve 12 saat sonra tekrar 12 derivasyon EKG'leri çekildi ve yine eş zamanlı olarak SKB, DKB, OKB, KAH ve $\mathrm{SpO} 2$ değerleri kaydedildi. EKG kayıtları $1 \mathrm{mV}$ yüksekliğinde ve $25 \mathrm{~mm} / \mathrm{s}$ hızında gerçekleştirildi. EKG kayıtlarındaki tüm derivasyonlar arasından en uzun QT mesafesi, grupları bilmeyen 2 anestezist tarafından ölçülerek ve aynı derivasyondaki RR mesafesi ölçülerek QTc (düzeltilmiş QT) mesafesi Bazzet formülüyle hesaplandı (QTc=QT intervali $\sqrt{ }$ RR intervali). Hesaplanan QT ve QTc değerleri kaydedildi.

Bulgular: 12. saatteki KAH değerlendirildiği zaman, dexmedetomidin grubundaki KAH, midazolam ve propofol grubundaki KAH'a göre istatistiksel olarak anlamlı bir şekilde düşüktü $(p<0,05)$. 12. Saatteki OKB değerlendirildiğinde, propofol grubundaki OKB, dexmedetomidin grubundaki OKB göre istatistiksel olarak anlamlı bir şekilde düşüktü $(\mathrm{p}<0,05)$. 12. Saatteki SpO2 değerlendirildiğinde, midazolam grubundaki SpO2, diğer 2 gruptaki SpO2 değerlerine göre istatistiksel olarak anlamlı bir şekilde düşüktü $(\mathrm{p}<0,05)$. QT intervali için; dexmedetomidin diğer 2 ajana göre QT intervalini hem 1. hem de 12. saatte daha çok uzattı, bu bulgu istatistiksel olarak anlamlıydı $(p<0,05)$. 12. saatte QT intervallerinde propofol ve midazolam grupları arasında istatistiksel olarak anlamlı bir fark vard1 $(p<0,05)$. QTc intervalleri değerlendirildiği zaman, sadece 12. saatteki QTc değerleri gruplar arasında farklıydı ve bu fark istatistiksel olarak anlamlıydı $(\mathrm{p}<0,05)$. QTc intervalini en çok dexmedetomidin uzattı, ancak propofolün QTc intervalini kısaltıcı etkisi ajanı daha çok tercih edilebilir kılıyor.

Sonuç: Bize göre; uzun QT intervali olan hastalarda propofol QT kısaltıcı etkisiyle, dexmedetomidin ve midazolama iyi bir alternatif sedatif ajandır. Dexmedetomidin ve midazolam QT intervalini uzatarak kardiak aritmiye sebep olabilir. YBÜ hastalarında sedasyon için ilaç seçimi yaparken, hastanın klinik durumu, hemodinamik parametreleri ve kardiyak monitörizasyonu iyi değerlendirilmelidir.

Anahtar sözcükler: Propofol, midazolam, dexmedetomidin, sedasyon, QT intervali

\section{INTRODUCTION}

Sedation is mostly needed for patients using mechanical ventilation (MV) in intensive care units (ICU) even if they are unconscious. In ICU, sedation is indicated for the treatment of anxiety (real or from psychophysiologic response caused by predicted danger) and agitation (excitability with body movements involved) ${ }^{1}$. In ICU, $40 \%$ of the patients state that they suffer from pain and $87 \%$ of them say that they feel discomfort ${ }^{2}$. Doses of the drugs that are used as routine and their superiority over eachother are still being discussed.

Ventilation support is commonly used on ICU patients to supply enough oxygenation ${ }^{3,4}$ and this is a reason for anxiety by itself. To get the optimum benefit from mechanical ventilation treatment and prevent incoherence with the ventilator, neuromuscular blockers should be used alongside sedative agents ${ }^{5}$. In addition, pain and agitation can cause immune-supression and hypercoagulopathy alongside an increase of oxygen consumption in the myocard.

Inefficient sedation of patients causes symptoms like hypertension, tachicardia, hypoxia and hypercapnia and struggling with the ventilator. On the other hand, excessive sedation can cause unwanted situations like hypotension, bradycardia, coma, respiration depression, ileus, renal failure, venose stasis, immune-supression ${ }^{6,7}$. Another thing that can happen to ICU patients is agitation ${ }^{8}$.

These negative factors can be prevented by applying sedation. In addition, the time spent at both mechanical ventilation and ICU can be shortened. Despite the obvious clinical benefits of sedative agents, their side effects make the choice for the appropriate drug and its dose harder. In many trials, the effects (hemodynamic, respiratory, appropriate sedation, stress response, preventing agitation and the ability of usage over a long period of time) of drugs that are used in ICU have been evaluated.

Length of QT intervals is primarily controlled by late rectifying ventricular potassium current and blocking the fast component of this current with drugs is said to be the most important reason behind life threatening "TORSADE DE POINTES" (twisting of the points) type arythmias (polymorphic ventricular tachicardias) ${ }^{9}$.

The goal of this study was to find out the effects of midazolam, propofol and dexmedetomidine infusion in ICU on QT intervals. 


\section{METHOD}

In this prospective study 90 patients at the age of 30-90 were included, who were brought to the intensive care unit with respiratory insuffiency and connected to the mechanical ventilator in Intensive Care Unit of Anesthesiology and Reanimation Department between 2014 July-October, after the approval of the ethical committee and written consents from patients were acquired. Patients using anticholinergic, antiaritmic, vasopressor, vasodilatator and hypotensive drugs, with electrolyte imbalance, unstable hemodynamics and acquired or congenital long QT syndrome (QT > $440 \mathrm{~ms}$ ) were not included in the study. Patients who did not give a written consent or whose relatives did not allow it were also not included. Patients who had changes in consciousness, hemodynamic instabilities, need for an endotracheal tube change and patients who needed to use anticholinergic, antiaritmic, vasopressor and vasodilatator drugs were removed from the study even if they were included before.

After respiratory and cardiac monitorization were supplied in patients who were transferred to the intensive care unit because of respiratory insufficiency, their 12 derivation ECG were taken and their systolic blood pressure (SBP), diastolic blood pressure (DBP), mean blood pressure (MBP), heart rate (HR), oxygen saturation $\left(\mathrm{SpO}_{2}\right)$ values were noted. These values were used as a base at hour 0 . After 1 hour and 12 hours of sedation (midazolam, propofol or dexmedetomidin) their 12 derivation ECG and SBP, DBP, MBP, HR and $\mathrm{SpO}_{2}$ values were taken again. ECG records were taken at $1 \mathrm{mV}$ height and $25 \mathrm{~mm} / \mathrm{s}$ speed. The longest QT interval among all the derivations and the RR interval on the same derivation were measured by 2 anesthetists who did not know the groups, and QTc intervals (corrected QT) were calculated with the Bazzet formula
(QTc=QT interval / $\sqrt{ } \mathrm{RR}$ interval). The calculated QT and QTc valueswere noted.

Sedative drug doses were titrated with doses stated above and with Ramsey Sedation Skala=3.

The study was conducted in the Intensive Care Unit of Anesthesiology and Reanimation Department. Hemodynamic and respiratory values of the study were acquired from a Drager branded XL model monitor. ECG was performed on a Mortara branded device. Parameters and sedatives used in the study are used routinely on the included patients. 2. and 3. ECGs were exclusive to the study, and ECG papers were provided by the researcher.

The sedative agent for the patients (midazolam, propofol, dexmedetomidine) were not chosen, but the most proper sedative agent was applied to the included patient. After the study was finished, presedation and post-sedation values (QT in ECG, Blood Pressure, Heart Rate) were compared. The obtained data were statistically analysed using SPSS (V22;0) program, evaluated using parametric test assumptions, variance analysis, Tukey test, significance test between pairs, and if parametric test assumptions could not be performed KruskalWallis test, Mann-Whitney U test, Wilcoxon test and Chi-Square test with the margin of error $=0.05$. A power analysis based on a pilot study showed that 3 groups of 30 patients each with $\alpha=0.05$ and $\beta=0.20$.

\section{RESULTS}

90 patients were included in the study. Of these patients, $35(38,9 \%)$ were male, and $55(61,1 \%)$ were female. The average age of these 90 patients was $72,6 \pm 15,4$. Glasgow Coma Scale evaluation showed an average score of $7.71 \pm 2.66$. When the groups were analyzed by age and gender range, the groups showed homogeneity within (Levene Test 0.053 ), and no significant difference was observed between the groups $(\mathrm{p}>0.05)($ Table 1$)$.

Table1. Range of patient's age averages and genders based on sedation type

\begin{tabular}{|c|c|c|c|}
\hline & $\begin{array}{c}\text { Midazolam } \\
(\mathbf{n}=\mathbf{3 0})\end{array}$ & $\begin{array}{c}\text { Propofol } \\
(\mathbf{n}=\mathbf{3 0})\end{array}$ & $\begin{array}{c}\text { Dexmedetomidine } \\
(\mathbf{n}=\mathbf{3 0})\end{array}$ \\
\hline $\begin{array}{c}\text { AGE (Years) } \\
\text { Mean } \pm \text { SD }\end{array}$ & $73.5 \pm 16.32$ & $73,33 \pm 16.09$ & $71,10 \pm 14,14$ \\
\hline $\begin{array}{c}\text { GENDER } \\
\text { Male/Female) }\end{array}$ & $11 / 19$ & $10 / 20$ & $14 / 16$ \\
\hline
\end{tabular}


When we analyzed the effects of sedation type on heart rate, we could not find a significant difference between the sedative agents after 0 and 1 hours $(p>0.05)$. After 12 hours, heart rates in the Midazolam and Propofol groups did not differ, however heart rates in the Dexmedetomidine group were significantly lower than the heart rates in the other two groups $(\mathrm{p}<0.05)$.

When we calculated the heart rates as a percentage of the initial heart rates and observed them by time, we saw that after 1 hour, the heart rate was lowered by $7 \%$ by midazolam, $8 \%$ by propofol and $9 \%$ by dexmedetomidine, and that there were no significant differences between these changes. Whereas after 12 hours, decreases in heart rates were $11 \%$ for midazolam, $14 \%$ for propofol and $27 \%$ for dexmedetomidine. While heart rate changes in the Midazolam and Propofol groups did not differ, we saw that Dexmedetomidine lowered the heart rates significantly more than the other two groups $(\mathrm{p}<0.05)$ (Figure1).
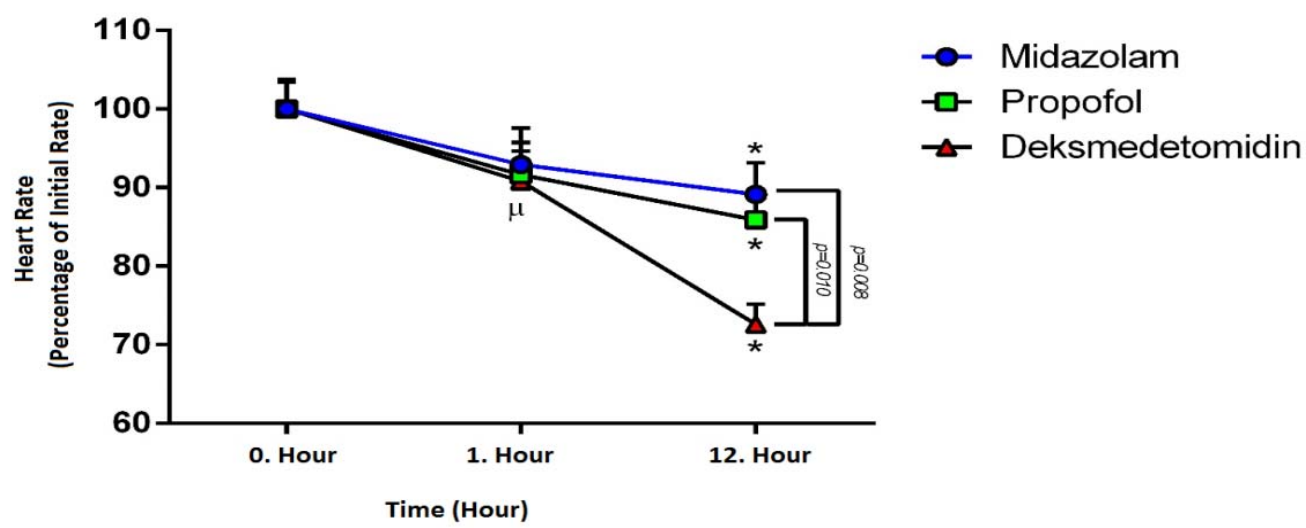

Figure 1. Change of patient's heart rates in percentage based on sedation type

*The drop in heart rate caused by the same agent is significantly different than the heart rate at 0 . hour $(\mathrm{p}<0.05)$. $\boldsymbol{\mu}$ Difference between the decreases in heart rate caused by dexmedetomidine after 1 and 12 hours is significant $(\mathrm{p}<0.05)$.

When the effects of sedative agents on heart rate were evaluated in themselves, we saw that after 12 hours, heart rate deceleration of midazolam and propofol was significantly different than the deceleration after 0 and 1 hour. $(p<0.05)$, and no significant difference was observed between 0 . and 1. hour. But when the heart rate deceleration of dexmedetomidine was analyzed, we observed that the 12. hour deceleration was significantly different than both 0 . and 1 . hour heart rate $(\mathrm{p}<0.05)$ (Figure1).
When we analyzed the effects of sedation type on mean arterial pressure (MAP), no significant difference in MAP was found between various sedative agents after 0 and 1 hours $(\mathrm{p}>0.05)$. When MAPs were evaluated at 12 . hour, no difference in MAPs between Midazolam and Dexmedetomidine groups were found, however the MAP in the Propofol group was significantly lower than the MAP in the Dexmedetomidine group $(\mathrm{p}<0.05)$ (Figure2). 


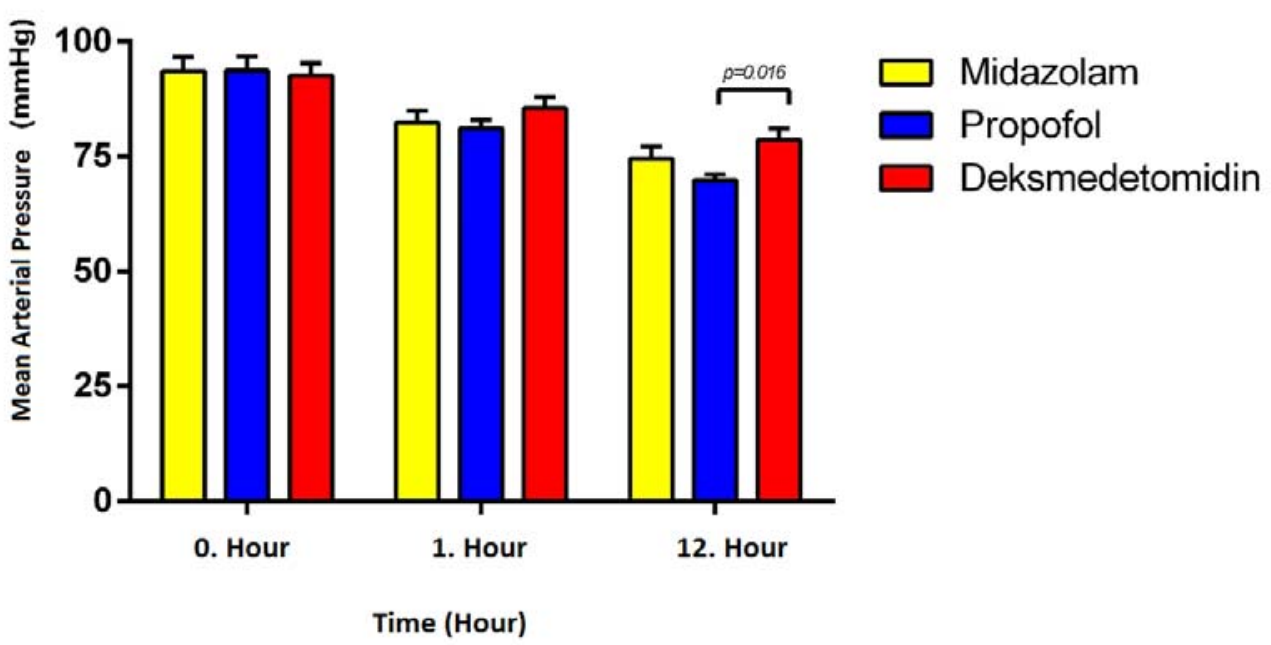

Figure 2. Range of patient's mean arterial pressures based on sedation type

When the effects of sedative agents on MAP were evaluated in themselves, we observed that there was a significant difference between 0 . and 12 . hour of all three agents $(\mathrm{p}<0.05)$. Midazolam dropped the MAP significantly much after 1 hour $(p<0.05)$, but there was nosignificant difference between 1. hour drop and 12. hour drop. Propofol dropped the MAP most among these 3 sedative agents, and there was asignificant difference in MAP change between 0 . and 1. hour, as well as 1 . and 12. hour $(\mathrm{p}<0.05)$. When Dexmedetomidine was analyzed, only the 12 . hour and 0 . hour MAP drops had a significant difference $(\mathrm{p}<0.05)$ (Figure3).

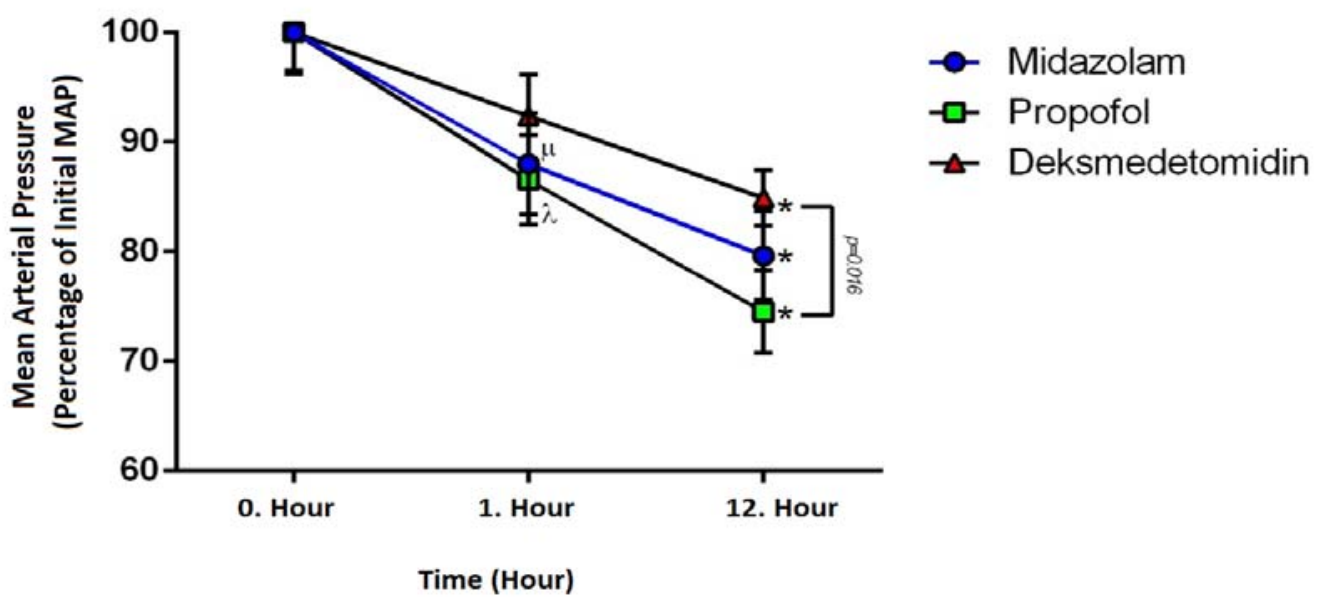

Figure 3. Change of patient's MAPs in percentage based on sedation type 
When we analyzed the effects of sedation type on $\mathrm{SPO} 2$, no significant difference in $\mathrm{SPO} 2$ was found between various sedative agents after 0 and 1 hours $(p>0.05)$. When SPO2 values were evaluated at 12 . hour, we saw that the SPO2 values in the Midazolam group were significantly lower compared to the other groups $(p<0.05)$. No significant difference was observed between the SPO2 levels in Propofol and Dexmedetomidine groups ( $\mathrm{p}>0.05$ ).

When we calculated the SPO2 values as a percentage of the initial SPO2 values and observed them by time, we saw that after 1 hour, SPO2 was increased by $2,1 \%$ by midazolam, $1,8 \%$ by propofol and $0,88 \%$ by dexmedetomidine, and that there were no significant differences between these changes. Whereas at the 12 . hour, increases in SPO2 were $2,13 \%$ for midazolam, $4,45 \%$ for propofol and 3,38\% for dexmedetomidine. While SPO2 changes in the Midazolam and Dexmedetomidine groups were significantly different $(p<0.05)$, no significant difference was seen between the Propofol and Dexmedetomidine groups (Figure 4).

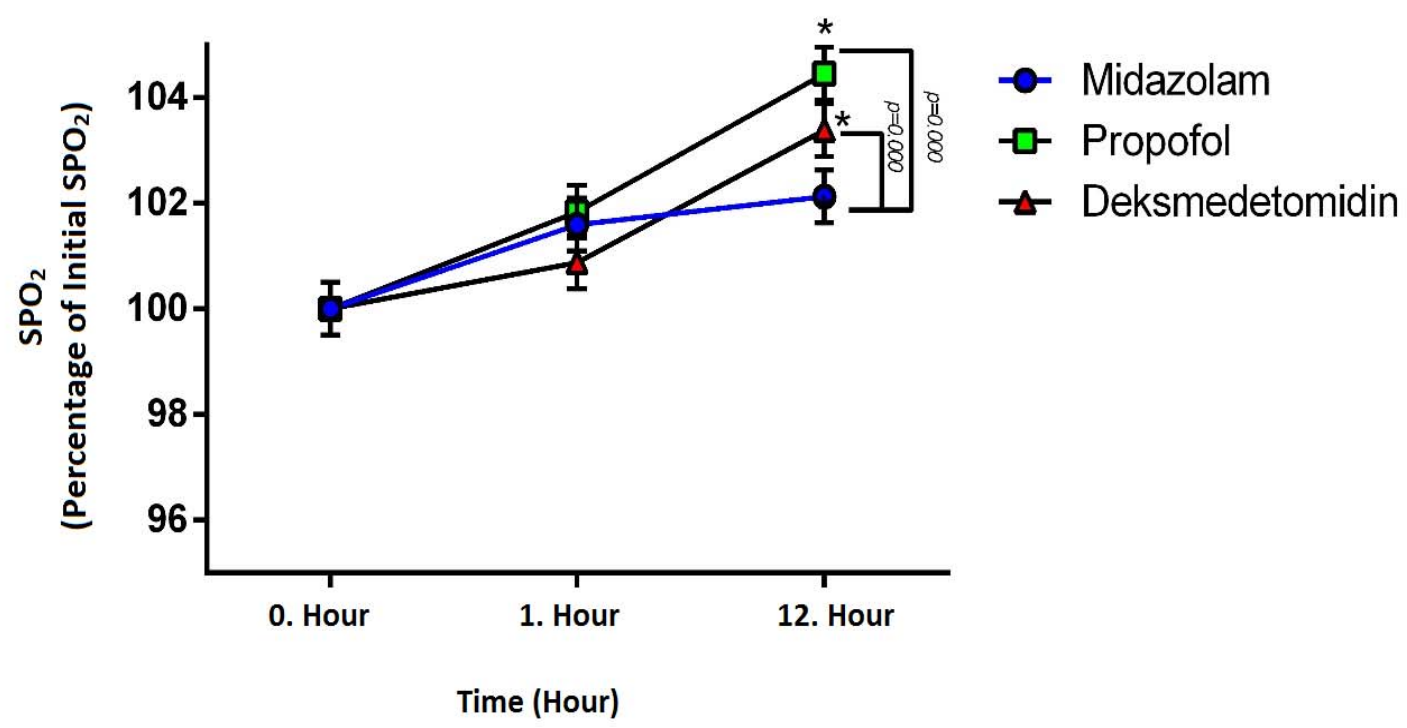

Figure 4. Change of patient's $\mathrm{SPO}_{2}$ values in percentage based on sedation type $* \mathrm{SPO}_{2}$ values after 0 and 1 hours of the same agent are significantly different $(\mathrm{p}<0.05)$.

When the effects of sedative agents on $\mathrm{SPO}_{2}$ were evaluated in themselves, we observed that there was a significant between 0 . and 12 . hour of Propofol and Dexmedetomidine $(p<0.05)$. We could not find any significant difference between 0., 1. and 12. hour $\mathrm{SPO}_{2}$ values in the Midazolam group (Figure4).
When we analyzed the effects of sedation type on QT and QTc, no significant difference was found between various sedative agents after 0 hour for QT intervals, and after 0 and 1 hours for QTc intervals $(\mathrm{p}>0.05)$. Dexmedetomidine extended QT intervals significantly more than the other 2 agents both after 1 and 12 hours $(p<0.05)$. While there was no significant difference between midazolam and propofol after 1 hour, there was a significant difference between QT intervals in these 2 groups $(\mathrm{p}<0.05)$. When the QTc intervals were analyzed; only the 12. hour QTc values were different with various sedative agents and all the QTc values in these groups we significantly different $(\mathrm{p}<0.05)$ (Figure 5,6). 


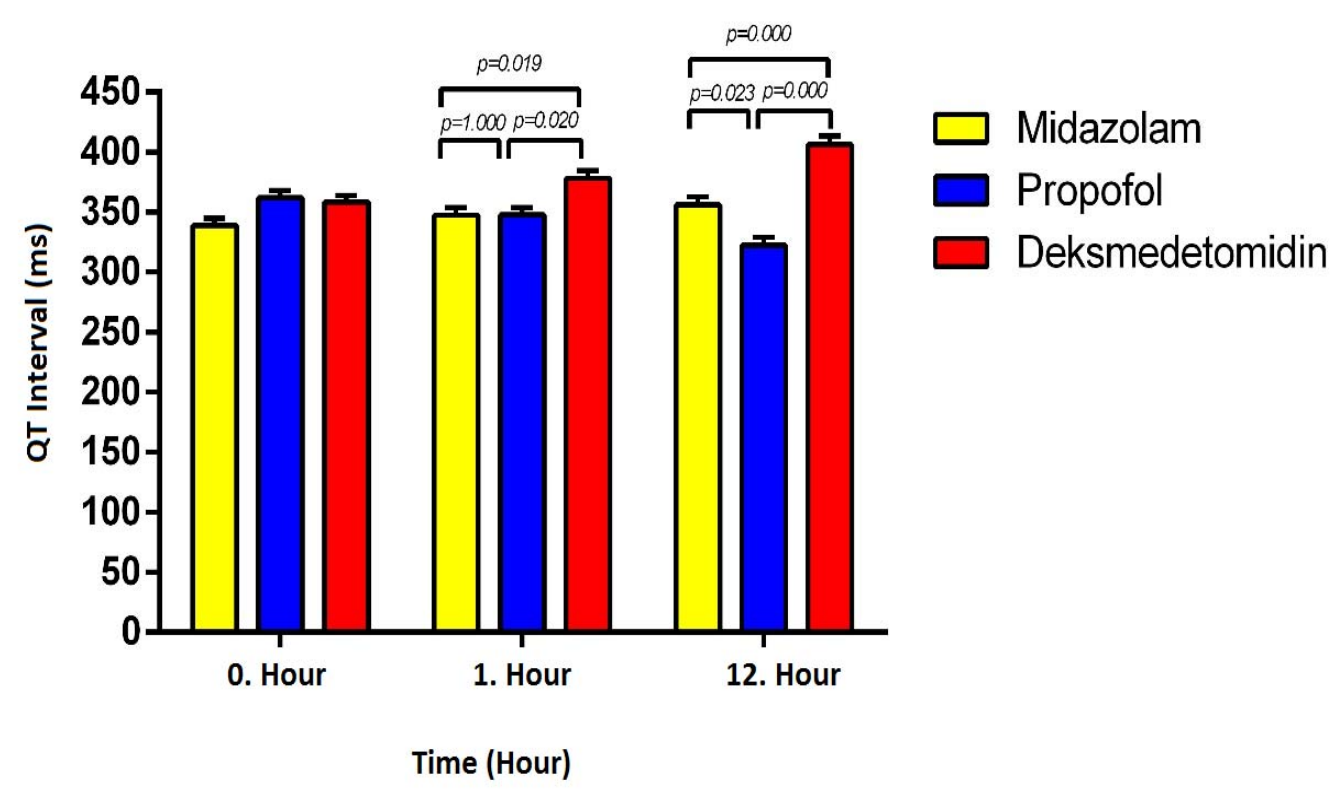

Figure 5. Range of patient's QT Intervals based on sedation type

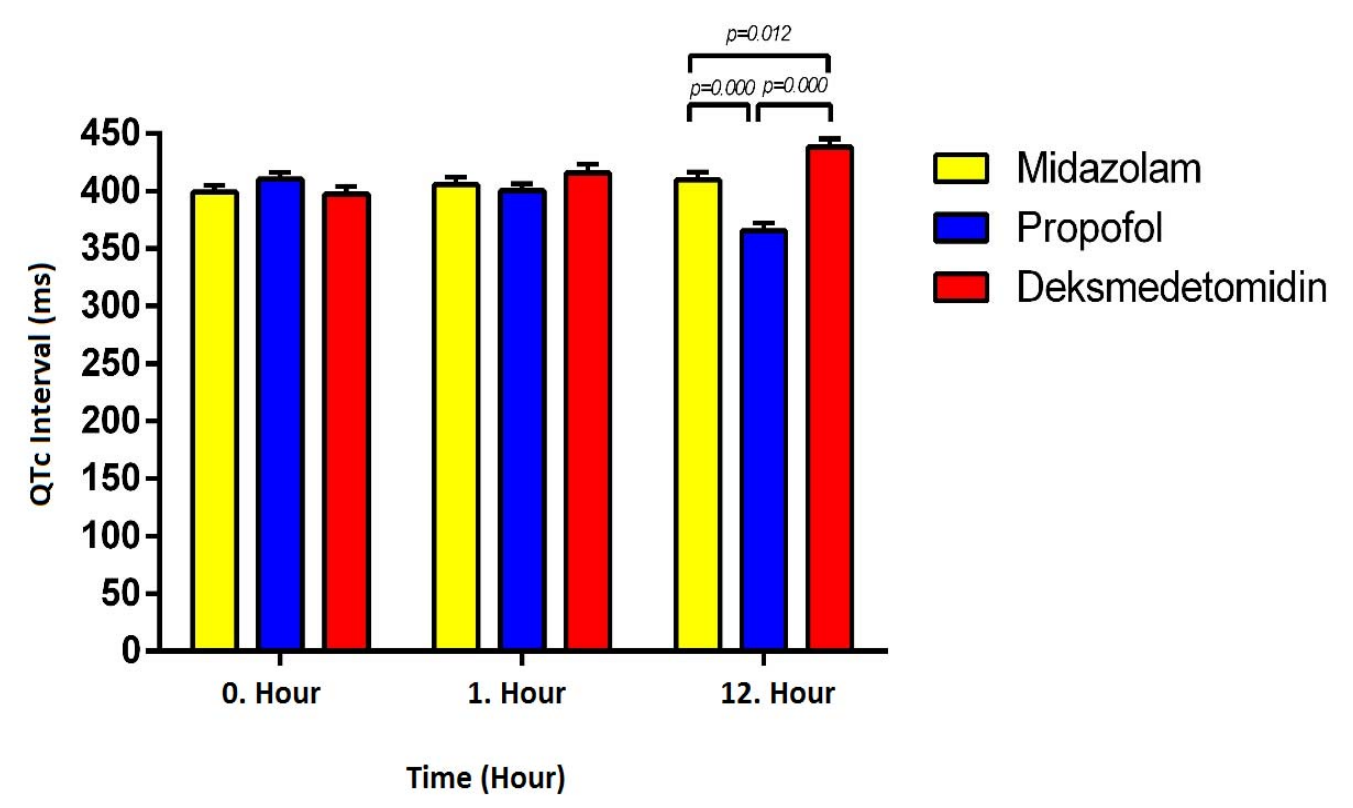

Figure 6. Range of patient's QTc (Corrected QT) intervals based on sedation type

When we calculated the QT and QTc values as a percentage of their initial values and observed them by time, we saw that after 1 hour, QT was extended by $2,6 \%$ by midazolam, and $10,3 \%$ by dexmedetomidine and shortened by $11 \%$ by propofol, and when these changes were compared to eachother, we observed that there was no significant difference between the midazolam and propofol groups and that there was a significant difference between midazolam-dexmedetomidine and propofol-dexmedetomidine groups $(\mathrm{p}<0.05)$ (Figure 7). 


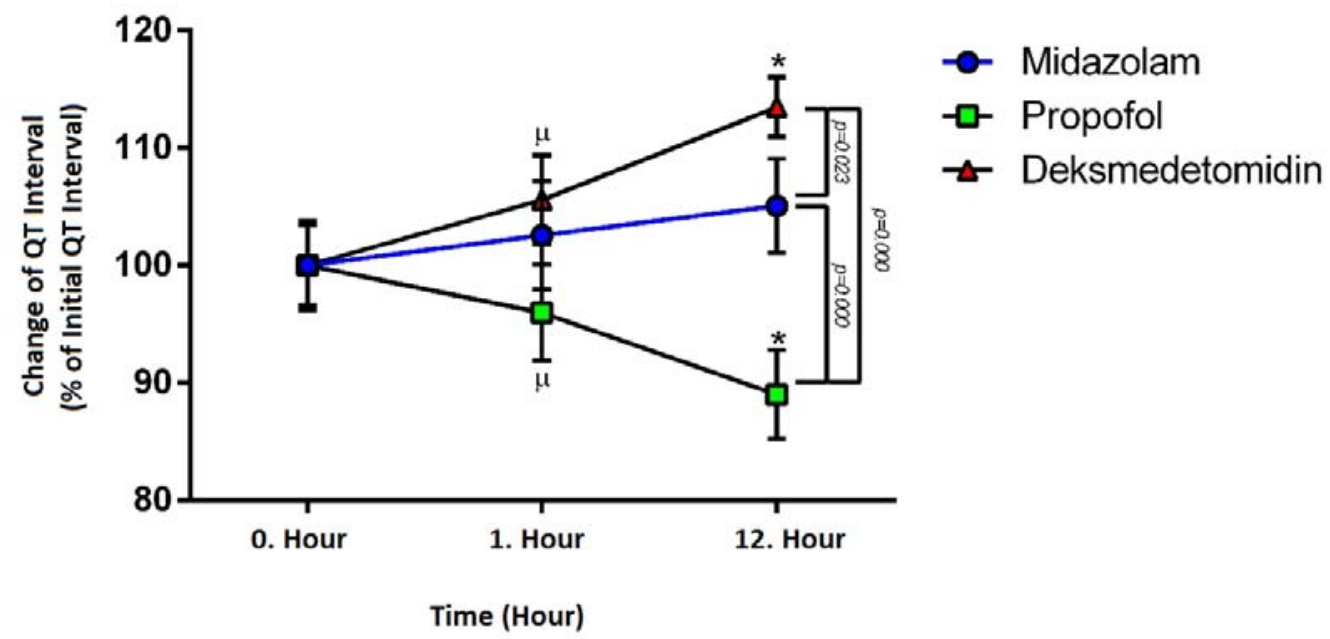

Figure 7. Change of patient's QT Intervals in percentage based on sedation type *Significantly different when compared to the 0 . hour QT interval of the same agent $(\mathrm{p}<0.05)$. ${ }^{\mu}$ Significantly different when compared to the 12 . hour QT interval of the same agent $(\mathrm{p}<0.05)$.

After 1 hour, QTc was extended by $2,6 \%$ by midazolam and $10,3 \%$ by dexmedetomidine and shortened by $11 \%$ by propofol, and there was no significant difference between these changes. After 12 hours, QT was extended by $7 \%$ by midazolam and $13,4 \%$ by dexmedetomidine and shortened by $11 \%$ by propofol. QT intervals of all three sedative agent groups had significant difference after 12 hours $(\mathrm{p}<0.05)$. After 12 hours, QTc was extenden by $3,9 \%$ by midazolam and $10,3 \%$ by dexmedetomidine and shortened by $14 \%$ by propofol. QTc intervals of all three sedative agent groups were significantly different $(p<0.05)$.

When the effects of sedative agents on QT and QTc intervals were evaluated in themselves, we observed a significant difference between propofol and dexmedetomidine 0 . and 12 . hours $(\mathrm{p}<0.05)$. There wasn't any significant difference between $0 ., 1$. and 12. hours of midazolams QTe values (Figure 8). While Dexmedetomidine extended QTc intervals the most, Propofol showed positive activity by shortening it, let alone extending it.

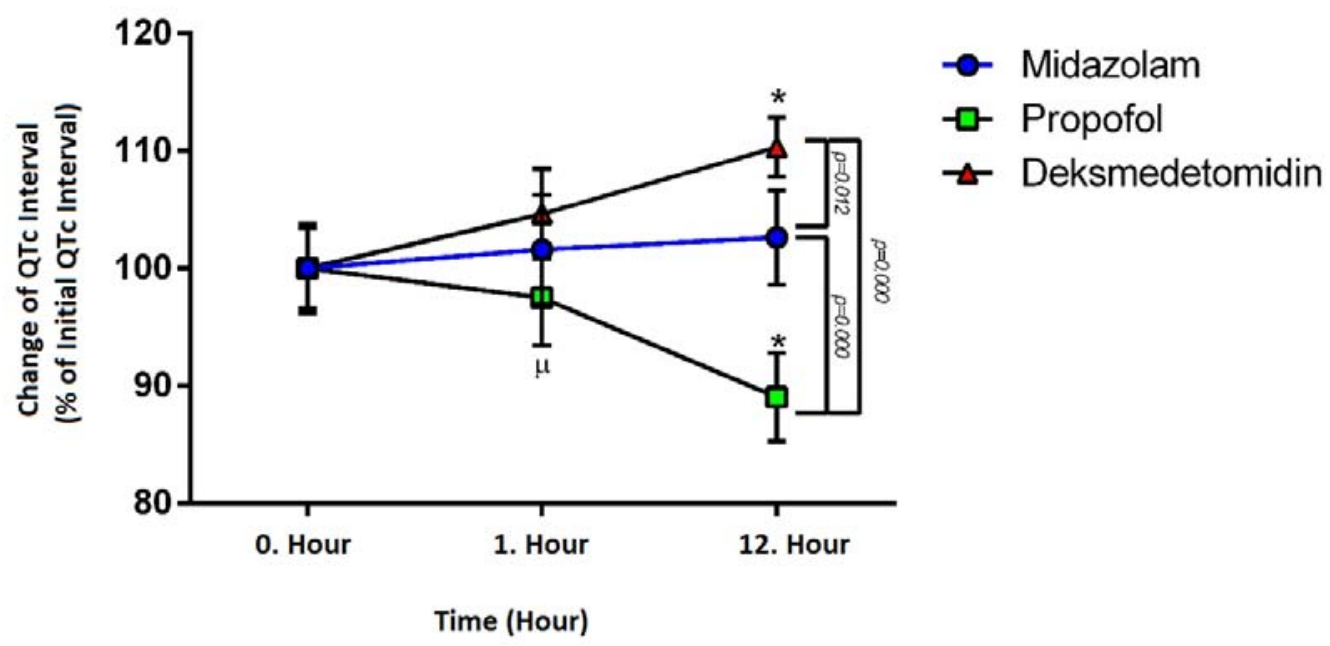

Figure 8. Change of patient's QTc Intervals in percentage based on sedation type

*Significantly different when compared to the 0 . hour QTc interval of the same agent $(\mathrm{p}<0.05)$.

${ }^{\mu}$ Significantly different when compared to the 12 . hour QTc interval of the same agent $(\mathrm{p}<0.05)$. 


\section{DISCUSSION}

In the intensive care unit, tranquilisers like opiates, benzodiazepines, propofol and haloperidol are commonly used. All these agents are dose dependent sedatives. Dexmedetomidine, Midazolam and Propofol are frequently used in intensive care sedations. There are no studies where all three sedative agents are evaluated in hemodynamic, cardiac and oxygenation terms.

Midazolam, Propofol and Dexmedetomidine are frequently used for intensive care sedations in our clinic. These agents were also used in our study. In a study by Wunsch et al. In another study by Salluh et al., sedation applications of Brasilian intensive care doctors were analyzed andmore than half of the applicants received a sedation protocol, and midazolam (97,8\%), fentanil (91,5\%) and propofol $(55 \%)$ were used commonly as sedatives ${ }^{10}$.

Similar to our study; in a study by Kaygusuz et al. where hemodynamic and oxygen transportation effects of sedative agents with patients using mechanical ventilation in intensive care units were investigated, they observed that midazolam and propofol infusions caused drops in heart rate ${ }^{11}$. In another study by M. Hacer Ulger et al. where they used dexmedetomidine, they observed a drop in heart rate and atropine-responsive bradycardia in 3 patients $^{12}$. A study by Tan et al. showed that the bradycardia incidence for dexmedetomidine was higher than the other agents ${ }^{13}$. Another study by Venn et al. where they compared the effects of dexmedetomidine and propofol on 20 intensive care patients, showed lower $\mathrm{HR}$ in the dexmedetomidine group than the propofol group ${ }^{14}$. Jalowiecki et al. observed higher bradycardia risk with dexmedetomidine in their study ${ }^{15}$. When dexmedetomidine and midazolam were compared for patients who were non-invasive mechanical ventilated, lower HR values were observed in the dexmedetomidine group. But distinctly from our study, midazolam HR values did not differ from their base values ${ }^{16}$. Likewise a study by Derbent et al. showed no changes in HR for propofol on intensive care patients using mechanical ventilation $^{17}$. Another study where dexmedetomidine, midazolam and propofol were compared for neurosurgery patients who needed postoperative mechanical ventilation, showed that HR dropped with all 3 drugs, but there were no significant difference between them ${ }^{18}$. In our study, HR values dropped with dexmedetomidine, midazolam and propofol as well, but the drop in the dexmedetomidine group was significantly more. The study by Paliwal et al. where dexmedetomidine and midazolam were used for mechanical ventilated intensive care patients shows similar results to our study ${ }^{19}$.

Blood pressure changes in sedated patients should be monitored carefully, because intensive care patients usually consist of patients with limited cardiac reserve. In our study; mean arterial pressures (MAPs) were not significantly different between groups after 0 and 1 hours. However after 12 hours Propofol caused a more significant decrease in MAP. In all 3 groups after both 1 and 12 hours, MAP values were lower than their base values. This decrease was similar in all groups after 1 hour, and more obvious in the propofol group after 12 hours. It should be considered that the average age of included patients is relatively high and this could be the cause of hypotension. In a study by Bloor et al., $1 \mathrm{mcg} / \mathrm{kg}$ dexmedetomidine infusion was applied to 6 healthy male volunteers for 2 minutes, and a significant decrease of $23 \%$ in blood pressure occured ${ }^{20}$. Arain et al. compared dexmedetomidine and propofol in their studies, and found that dexmedetomidine was superior because it caused less hypotension ${ }^{21}$. Weinbroum et al. reported that for intensive care patients, propofol caused more cardiovascular depression than midazolam ${ }^{22}$. Again similar to our study; dexmedetomidine and propofol were compared for sedation in mechanical ventilated IC patients in a study, and MAP values in both groups were lower than their base values. The decrease in the propofol group was more than the decrease in the dexmedetomidine group ${ }^{19}$.

Distinctly from our study; Tan et al. reported that there is no significant difference between dexmedetomidine and other sedative agents in terms of hypotension side effect ${ }^{13}$. A study by Venn et al. showed that there is no significant difference between dexmedetomidine and propofol when it comes to their effects on endocrine, metabolic, inflammatory and cardiac systems after a major surgery ${ }^{14}$. Dexmedetomidine, midazolam and propofol were applied to neurosurgery patients who needed mechanical ventilation in postoperative intensive care and compared in a study. MAP decreased with all 3 drugs, and this drop was similar for each of them ${ }^{18}$.

Mechanical ventilation is commonly used for intensive care patientsto provide enough oxygenation. To get the optimum benefit from 
mechanical ventilation treatment and prevent incoherence with the ventilator, sedative agents are used $^{4,5}$. Therefore sedative agents should have positive effects on intensive care patients with mechanical ventilator. We used $\mathrm{SPO}_{2}$ in our study, which is an indicator for oxygenation. While sedation types did not show any differences in $\mathrm{SPO}_{2}$ values after 0 and 1 hours, the $\mathrm{SPO}_{2}$ values in propofol and dexmedetomidine groups were higher than the values in the midazolam group after 12 hours. While all sedative agents increased $\mathrm{SPO}_{2}$ levels after 1 hour of sedation, the most obvious increase was with propofol after 12 hours. The least increase was with midazolam. Sedative agents increased the $\mathrm{SPO}_{2}$ level as expected, but the singificant and obvious increase was with propofol. With these findings it can be said that the best results with mechanical ventilation can be achieved with propofol.

In a study by Gupta et al. with 40 mechanical ventilated intensive care patients, they applied midazolam or dexmedetomidine to the patients so that the Ramsey Sedation Score would be 2-4. After sedation, $\mathrm{SPO}_{2}$ values in both groups increased. But this increase was not significant whencompared to the base values. Dexmedetomidine increased $\mathrm{SPO}_{2}$ levels significantly more than midazolam ${ }^{23}$. This was also the case with our study, dexmedetomidine achieved higher $\mathrm{SPO}_{2}$ levels than midazolam. In a study including 33 intensive care postoperative patients, Venn et al. reported that with dexmedetomidine sedation, $\mathrm{paO}_{2}: \mathrm{FiO}_{2}$ ratio was higher than sedation without dexmedetomidine ${ }^{24}$. Huang et al. compared dexmedetomidine and midazolam in a study including 62 intensive care patients. After sedation with a Ramsey Sedation Score of 2-3, both groups had an increase in $\mathrm{SpO}_{2}$ and $\mathrm{PaO}_{2}: \mathrm{FiO}_{2}$ ratio. But this increase was not different from each other ${ }^{25}$.

There can be a lot of situations that can effect QT intervals in intensive care patients, like electrolyte anomalies. Especially hypokalemia, hypocalcemia and hypomagnesemia are frequently associated with QT prolongation ${ }^{26}$. Patients with electrolyte imbalances were excluded from our study. Many commonly used drugs in intensive cares are also associated with QT prolongation. Antiaritmics, antibiotics, antivirals, antiemetics, antidepressants, antipsychotics and narcotics have been reported to cause prolongation in QT dispersion ${ }^{27}$. While effects on QT of many drugs used for intensive care have been investigated, the effects of sedative agents which are commonly used in intensive cares are still unknown.
When we compared QT intervals of dexmedetomidine after both 1 and 12 hours with other agents, we observed that it extends the interval. After 12 hours, we saw that propofol shortened QT intervals. The variety of heart rates prevents the usage of QT intervals for determining arythmia risk. For this reason, corrected QT (QTc) interval is a more valuable parameter. There was no significant change in QTc intervals after 0 and 1 hours in our study. But after 12 hours of sedation, we observed a prolongation with dexmedetomidine, no change in midazolam and a shortage with propofol in QTc intervals. With the results of our study, we can say that dexmedetomidine should be used carefully because of its high mortal ventricular arythmia risk, and that propofol should be preferred because it shortens QTc intervals.

We could not find any research on sedative agents' effects on QT intervals for mechanically ventilated intensive care patients. For this reason, results in other areas of usage were used to compare dexmedetomidine, midazolam and propofol. In our study, propofol shortened QT intervals. In a 2005 study by Whyte et al. ${ }^{28}$ on propofol use for children; they reported that propofol shortened QT intervals, and that it can be used safely even for children with long-QT syndrome. Especially the relationship between QT intervals and single dose of $0,2-5 \mathrm{mg} / \mathrm{kg}$ propofol induction were analyzed in studies done with inhalation anesthetics and propofol, and it was reported that this dose range does not extend QT and that propofol is safe for children with QT prolongation ${ }^{29}$. Similar to that, Hanci et al. ${ }^{30}$ used sevofluran and propofol for anesthetic induction in their study, and reported no changes in QTc caused by propofol. Other researchers also reported that QT intervals do not change with propofol ${ }^{31,32}$. Similar to our study, Higashijima et al. ${ }^{33}$ did a study on 50 spinal surgery patients, where he compared thiamylal and propofol for induction, and reported a significant shortage of QT intervals caused by propofol. Kazanci et al. compared propofol, sevoflurane and desflurane in their study for induction on 46 general surgery patients and reported that propofol significantly shortens QT intervals ${ }^{34}$. There were no studies available that analyze QT intervals with the propofol doses we used. We think that studies reporting no QT interval changes with propofol support our results. Because in these studies, propofol was used for anesthetic induction, therefore with much higher doses than ours. Distinctly from this study, Kim et al. researched the effects of target controlled propofol infusion on QTc intervals in their study, and reported that QTc 
values extended significantly compared to the base values during propofol infusion and endotracheal intubation $^{35}$. In another study by Saarnivaara et al. which included 123 pediatric patients, propofol was reported to extend QT intervals ${ }^{36}$. In a study where Michaloudis et al. used midazolam and propofol on 30 patients for anesthetic induction, they observed no QT interval changes for both of the agents ${ }^{37}$. Results from their study coincide with the results from our study. In another study by Michaloudis et al. in 1995, they reported that midazolam did not change QT intervals ${ }^{38}$. Similar to that, a study including 40 patients done by Owczuk et al. showed that midazolam did not effect QT intervals ${ }^{39}$.

Apart from a few studies where dexmedetomidine's effects on QT intervals were investigated, no other studies are available. In 2008, during a pediatric ablation and electrophysiologic study by Hammer et al., a deceleration in sinus and atrioventricular node and a significant QTc prolongation were observed. They have reached the conclusion that the usage of dexmedetomidine on patients with bradyarythmia tendency increases the risk of QT interval prolongation $^{40}$. Their results are similar to our study's results. Distinctly from our study's results; Chrysostomou et al. researched electrocardiographic effects of dexmedetomidine on 0-17 year old pediatric intensive care patients. They reported that dexmedetomidine has no effect on QT intervals ${ }^{41}$. Likewise, in a study by Reade et al, haloperidol and dexmedetomidine were applied to 20 mechanical ventilated patients in intensive care. They observed that dexmedetomidine did not cause a significant QT interval prolongation ${ }^{42}$.

We reached a conclusion that for intensive care sedations, the following agents should be preferred: dexmedetomidine if the patient has tachycardia, propofol if their blood pressure is high, midazolam if their blood pressure and heart rate are low, propofol if their oxygenation is insufficient due to incoherence with mechanical ventilator and again propofol if they have long QT intervals.

\section{REFERENCES}

1. Ostermann ME, Keenan AP, Seiferling RA, Sibbald WJ. Sedation in the intensive care unit. JAMA 2000; 283: 1451-9.

2. Rotondi AJ, Chelluri L, Sirio C, et al. Patients' recollections of stressful experiences while receiving prolonged mechanical ventilation in an intensive care unit. Crit Care Med 2002; 30: 746-52.

3. Cristopher W, Brovvn B, Gutierez G: Gas transport and delivery. Textbook of Critical Çare, 2,Edition (Ed: Schoemaker WC). Philadelphia, W B Saunders Company: p 492-500, 1989.

4. Slutsky AS: Mechanical ventilation; ACCP concensus conference. Chest; 104:1833-1859, 1993.

5. Moral AR: Yoğun bakımda ventilatör desteği. Erciyes Tip Dergisi; 1995; 17: 4652.

6. Schelling G, Richter M, Roozendaal B, et al. Exposure to high stress in the intensive care unit may have negative effects on health related quality of life outcomes after cardiac surgery. Crit Care Med 2003; 31: 1071-9.

7. Devlin JW, Fraser GL, Kanji S, Riker RR. Sedation assessment in critically ill adults. Ann Pharmacother 2001; 35: 1624-32.

8. Crippen DW: The role of sedation in the ICU patient with pain and agitation. Crit Care Clin 1990; 6: 369-92.

9. Witchel HJ, Hancox JC. Familial and acquired long QT syndrome and the cardiac rapid delayed rectifier potassium current. Clin Exp Pharmacol P 2000; 27: 753-66.

10. Salluh JI, Dal-Pizzol F, Mello PV, Friedman G, Silva E, Teles JM, Lobo SM, Bozza FA, Soares M; Brazilian Research in Intensive Care Network. Delirium recognition and sedation practices in critically ill patients: a survey on the attitudes of 1015 Brazilian critical care physicians. J Crit Care 2009; 24: 556-62

11. Kaygusuz K, Gürsoy S, Kunt N, Kafalı H. Yoğun Bakımda Kullanılan Sedatif Ajanların Hemodinami Ve Oksijen Transportu Üzerine Etkileri. Erciyes Tip Dergisi 2004; 26: 165-177. 
12. Ülger MH, Demirbilek S, Köroğlu A, Borazan H, Ersoy MÖ: Orta kulak cerrahisinde deksmedetomidin ile kontrollü hipotansiyon. İnönü Üniversitesi Tıp Fakültesi Dergisi 2004; 11: 237-41.

13. Tan JA, Ho KM. Use of dexmedetomidine as a sedative and analgesic agent in critically ill adult patients: a meta-analysis. Intensive Care Med 2010; 36: 926-39.

14. Venn RM, Bryant A, Hall GM, Grounds RM. Effects of dexmedetomidine on adrenocortical function, and cardiovascular, endocrine and inflammatory responses in postoperative patients needing sedation in the intensive care unit. Br J Anaesth 2001; 86: 650-6.

15. Jalowiecki P, Rudner R, Gonciarz M, et al. Sole use of dexmedetomidine has limited utility for conscious sedation during outpatient colonoscopy. Anesthesiology 2005; 103: 269-73.

16. Nimet Senoglu, Hafize Oksuz, Zafer Dogan, Huseyin Yildiz, Hilmi Demirkiran, Hasan Ekerbicer. Sedation During Noninvasive Mechanical Ventilation With Dexmedetomidine or Midazolam: A Randomized, Double-Blind, Prospective Study. Curr Ther Res Clin Exp 2010; 71: 141-53.

17. Derbent A, Sakarya M, Derbent A, Moral AR. Yoğun bakımda mekanik ventilasyon uygulanan hastalarda propofol ile sedasyonun hemodinamik ve metabolik etkileri. Ege Tip Dergisi 2001; 40: 191-7.

18. Srivastava vk, Agrawal S, Kumar S, Mishra A, Sharma S, Kumar R. Comparison of Dexmedetomidine, Propofol and Midazolam for Short-Term Sedation in Postoperatively Mechanically Ventilated Neurosurgical Patients. J Clin Diagnostic Research 2014; 8: 4-7.

19. Paliwal B, Rai P, Kamal M, Singariya G, Singhal M, Gupta P, Trivedi T, Chouhan DS. Comparison Between Dexmedetomidine and Propofol with Validation of Bispectral Index For Sedation in Mechanically Ventilated Intensive Care Patients. J Clin Diagn Res 2015; 9: 1-5.

20. Bloor BC, Ward DS, Belleville JP. Effects of intravenous dexmedetomidine in humans.II.Hemodynamicchanges.Anesthe siology 1992; 77: 1134-42.
21. Arain SR, Ebert TJ. The efficacy, side effects, and recovery characteristics of dexmedetomidine versus propofol when used for intraoperative sedation. Anesth Analg 2002; 95: 461-6.

22. Weinbroum AA, Halpern P, Rudick V, et al. Midazolam versus propofol for longterm sedation in the ICU: a randomized prospective comparison. Int Care Med 1997; 23: 1258- 1263.

23. Gupta S, Singh D, Sood D, Kathuria S. Role of dexmedetomidine in early extubation of the intensive care unit patients. J Anaesthesiol Clin Pharmacol. 2015; 31: 92-8.

24. Venn RM1, Hell J, Grounds RM. Respiratory effects of dexmedetomidine in the surgical patient requiring intensive care. Crit Care 2000; 4: 302-8.

25. Huang Z1, Chen YS, Yang ZL, Liu JY. Dexmedetomidine versus midazolam for the sedation of patients with non-invasive ventilation failure. Intern Med 2012; 51: 2299-305.

26. Abriel H, Schlapher J, Keller DI, Gavillet B, Buclin T, Biollaz J et al. Molecular and clinical determinants of drugs- induced long QT syndrome: An iatrogenic channelopaty. Swiss Med Wkly 2004; 134 : 685-94.

27. Caitlin Kennelly C, Esaian D. DrugInduced Cardiovascular Adverse Events in the Intensive Care Unit. Crit Care Nurs Q. 2013; 36: 323-34.

28. Whyte SD, Booker PD and Buckley DG. The effects of propofol and sevoflurane on the QT interval and transmural dispersion of repolarization in children. Anesth Analg 2005; 100: 71-7.

29. Yamada M, Hatakeyama N, Malykhina AP, Yamazaki M, Momose Y, Akbarali HI. The effects of sevoflurane and propofol on QT interval and heterologously expressed human ether-A-Go-Go related gene currents in xenopus oocytes. Anesth Analg 2006; 102: 98-103.

30. Hanci V, Aydin M, Yurtlu BS, et al. Anesthesia induction with sevoflurane and propofol: evaluation of $\mathrm{P}$-wave dispersion, QTand corrected QT intervals. Kaohsiung J Med Sci 2010; 26: 470-7. 
31. Kleinsasser A, Kuenszberg E, Loeckinger A, Keller C, Hoermann C, Lindner KH, Puehringer F. Sevoflurane, but not propofol, significantly prolongs the Q-T interval: Anesth Analg 2000; 90: 25-7.

32. Sen S, Ozmert G, Boran N, Turan H, Caliskan E. Comparison of single-breath vital capacity rapid inhalation with sevoflurane $5 \%$ and propofol induction on QT interval and haemodynamics for laparoscopic surgery. Eur J Anaesthesiol 2004; 21: 543-6.

33. Higashijima U, Terao $Y$, Ichinomiya $T$, Miura K, Fukusaki M, Sumikawa K. A comparison of the effect on QT interval between thiamylal and propofol during anaesthetic induction. Anaesthesia 2010; 65: 679-83.

34. Kazanci D, Unver S, Karadeniz U, Iyican D, Koruk S, Yilmaz MB, Erdemli O. A comparison of the effects of desflurane, sevoflurane and propofol on QT, QTc, and $\mathrm{P}$ dispersion on ECG. Ann Card Anaesth. 2009; 12: 107-12.

35. Kim DH, Kweon TD, Nam SB, Han DW, Cho WY, Lee JS. Effects of target concentration infusion of propofol and tracheal intubation on QTc interval. Anaesthesia 2008; 63: 1061-4.

36. Saarnivaara L, Hiller A, Oikkonen M. QT interval, heart rate and arterial pressures using propofol, thiopentone or methohexitone for induction of anaesthesia in children. Acta Anaesthesiol Scand 1993; 37: 419-23.

37. Michaloudis DG, Kanakoudis FS, Petrou AM, Konstantinidou AS, Pollard BJ. The effects of midazolamor propofol followed by suxamethoniumontheQTinterval inhumans. Eur J Anaesthesiol 1996; 13: 364-8.

38. Michaloudis DG, Kanakoudis FS, Xatzikraniotis A, Bischiniotis TS. The effects of midazolam followed by administration of either vecuronium or atracurium on the QT interval in humans. Eur J Anaesthesiol 1995; 12: 577-83.

39. Owczuk R, Twardowski P, DylczykSommer A, et al. Influence of promethazine on cardiac repolarisation: a double-blind, midazolam-controlled study. Anaesthesia 2009; 64: 609-14.
40. Hammer GB, Drover DR, Cao H, et al. The effects of dexmedetomidine on cardiac electrophysiology in hildren. Anesth Analg 2008; 106: 79-83.

41. Chrysostomou C, Komarlu R, Lichtenstein S, Shiderly D, Arora G, Orr R, Wearden PD, Morell VO, Munoz R, Jooste EH. Electrocardiographic effects of dexmedetomidine in patients with congenital heart disease. Intensive Care Med 2010; 36: 836-842.

42. Reade MC, O'Sullivan K, Bates $\mathrm{S}$, Goldsmith D, Ainslie W, Bellomo R. Dexmedetomidine vs. haloperidol in delirious, agitated, intubated patients: a randomised open-label trial. Critical Care 2009, 13:R75. 